\title{
Detection of genes mediating beta-lactamase production in isolates of enterobacteria recovered from wild pets in Saudi Arabia
}

\author{
Sabry A. Hassan ${ }^{1,2}$ and Mohammed Y. Shobrak ${ }^{1}$
}

1. Department of Biology, Faculty of Science, Taif University 888, Taif, Saudi Arabia; 2. Department of Microbiology, Faculty of Veterinary Medicine, South Valley University 83523, Qena, Egypt.

Corresponding author: Sabry A. Hassan, e-mail: sabryh@lycos.com, MYS: mshobrak@gmail.com

Received: 24-08-2015, Revised: 19-10-2015, Accepted: 25-10-2015, Published online: 17-12-2015

doi: 10.14202/vetworld.2015.1400-1404 How to cite this article: Hassan SA, Shobrak MY (2015) Detection of genes mediating beta-lactamase production in isolates of enterobacteria recovered from wild pets in Saudi Arabia, Veterinary World 8(12): 1400-1404.

\begin{abstract}
Aim: To determine the genetic basis and types of beta-lactamase encountered among enterobacterial isolates of wild pets from the animal exhibit.
\end{abstract}

Materials and Methods: A total of 17 beta-lactamase-producing enterobacteria recovered from fecal samples of wild pet animals were analyzed for a selected beta-lactamase gene by polymerase chain reaction.

Results: Molecular analysis identified one or more $\beta$-lactamase-encoding genes in 14 enterobacterial isolates as a single or gene combination. The most frequent extended-spectrum $\beta$-lactamases types were TEM and CTX-M, and the most common AmpC enzymes were CMY-2 and DHA types.

Conclusions: The study is the first in Saudi Arabia, have established the presence of $\beta$-lactamase-encoding genes in the fecal isolates of wild pets.

Keywords: animal exhibit, extended-spectrum $\beta$-lactamases/AmpC beta-lactamase, fecal samples, polymerase chain reaction, Saudi Arabia.

\section{Introduction}

Antibiotic-resistant bacteria are extremely important to human health. The production of B-lactamases is the major mechanism of bacterial resistance to $\beta$-lactam antibiotics which are considered the most widely used class of antibiotics against both Gramnegative and Gram-positive bacteria. Resistance to this class of antimicrobial agents is therefore of immense clinical significance.

A major reason for resistance of Enterobacteriaceae to beta-lactam antibiotics is the production of extended-spectrum $\beta$-lactamases (ESBLs) and AmpC beta-lactamases, capable of inactivating the effects of broad-spectrum cephalosporins and penicillins [1]. Exposure to ESBL/ AmpC-producing microorganisms can occur through any means, but the hospital has always been thought to be the greatest risk [2]. The occurrence of ESBL/AmpC-producing microorganisms is on the rise globally, with prevalence varying from country to country and within a country from institution to institution [3]. The genes that encode for these enzymes may be plasmid-borne or chromosomally located.

Wild animals provide a biological mechanism for the spread of antibiotic resistance genes [4]. Recently, a number of studies describing the occurrence of ESBL-resistant Escherichia coli in wildlife [5-14].

Copyright: The authors. This article is an open access article licensed under the terms of the Creative Commons Attributin License (http:// creative commons.org/licenses/by/2.0) which permits unrestricted use, distribution and reproduction in any medium, provided the work is properly cited.
Data from the Arabian Peninsula, including Saudi Arabia, suggested that extended-spectrum and AmpC beta-lactam-resistant bacteria constitute a major problem in nosocomial and community-acquired infections $[15,16]$. However, there is scarce information on the occurrence and genetic characteristics of $\beta$-lactamase-producing bacteria in wild pet animals. Therefore, this study was carried to investigate the occurrence and distribution of beta-lactamase encoding genes within enterobacteria derived from wild pet animals in Saudi Arabia.

\section{Materials and Methods}

\section{Ethical approval}

The fecal samples were collected aseptically with adequate precautionary measures to minimize pain and/or discomfort to the animals and carried out in accordance with the Saudi animal welfare laws.

\section{Bacterial strains}

A total of 17 positive ESBL/AmpC enterobacterial isolates recovered from 75 fecal samples of wild animals at pet market, Taif, Western Saudi Arabia (5 rock hyrax, 4 Yemen Linnet, 3 common kestrel, 3 red foxes, 3 long-tailed finches, 2 caracal, 2 peacock, 1 rock dove, 1 hamadryas baboon, 1 orange-winged parrot, 1 Burmese python, 1 Hill Mynah, 1 African gray parrot, 1 common myna) were included. Wild animals are caught or bought for pet, shops, local breeder or traded (sometimes illegally). The enterobacterial isolates were 9 E. coli, and single isolates of Klebsiella pneumonia, Klebsiella oxytoca, Proteus mirabilis, Proteus 
vulgaris, Enterobacter cloacae, Enterobacter aerogenes, Citrobacter freundii, and Citrobacter youngae. Isolates were identified and confirmed by commercially available biochemical test (API tests; bioMérieux). The ESBLs and AmpC beta-lactamase production were achieved by commercially available Etest (bioMérieux).

\section{Molecular investigation}

Rapid DNA preparation was performed by a boiling technique that includes heating at boiling of an overnight bacterial culture $(200 \mu \mathrm{l})$ mixed with $800 \mu \mathrm{l}$ of distilled water, followed by cooling, centrifugation and the supernatant was used as the DNA template for the polymerase chain reaction (PCR).

The presence of genes encoding TEM, SHV, OXA, CTX-M, CMY-2, and DHA type $\beta$-lactamases was studied by multiplex PCR using universal primers and conditions previously reported $[17,18]$. The PCR was conducted in a Thermal Cycler PXE-0.5 (THERMO; Electron Corporation) and the resulting PCR products were subjected to electrophoretic separation in $1.5 \%$ agarose gel. Visualization of amplicons was completed by staining with ethidium bromide (Sigma-Aldrich) $(1 \mu \mathrm{g} / \mathrm{ml})$ under UV transluminator and photographed. DNA bands of each amplicon were compared with 100-bp DNA mass marker (Figure1a-c). Primers sequence and PCR condition are presented in Table-1.

\section{Results}

PCR detection of B-lactamase encoding genes

A total of 17 beta-lactamase positive enterobacterial strains recovered from the feces of wild pet animals were screened for beta-lactamase (bla)-encoding genes. The PCR screening identified the presence of the beta-lactamase genes encoding TEM, CTX-M, CMY-2, and DHA in 14 of them (Figure-1a-c). None

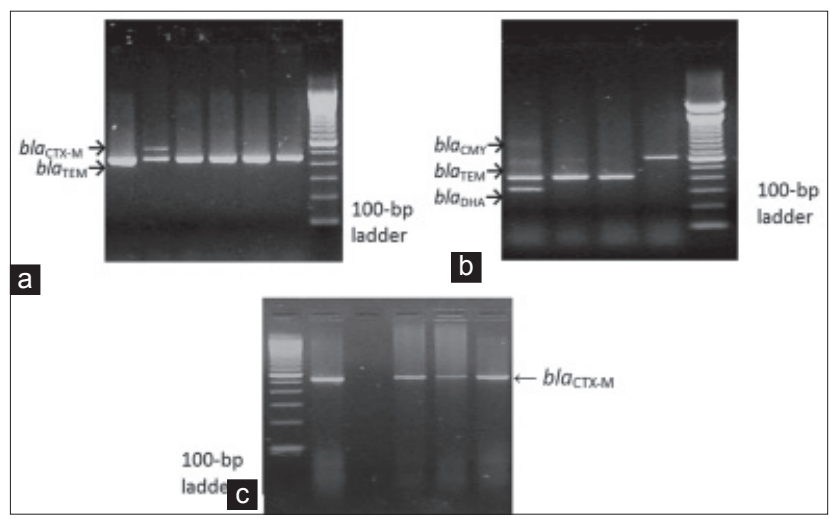

Figure-1: (a) The result of the multiplex polymerase chain reaction (PCR) amplification of the DNA target gene loci of 593-bp fragment DNA region coding for CTX-M; 431-bp fragment DNA region coding for TEM, (b) the result of the multiplex PCR amplification of the DNA target gene loci of: 695-bp fragment DNA region coding for CMY-2; 431bp fragment DNA region coding for TEM; 314-bp fragment DNA region coding for $D H A$, (c) the result of the multiplex PCR amplification of the DNA target gene loci of 593-bp fragment DNA region coding for CTX-M. of the isolates were reacted positively for $b l a_{\mathrm{OXA}}$ and $b l a_{\mathrm{SH} \mathbf{v}^{*}}$ No beta-lactamase genes were identified in the remaining three isolates.

Overall, variety of beta-lactamase genes were found within nine bacterial species isolated from various wild pets species. TEM enzyme was detected in nine isolates of beta-lactamase-producing, respectively, which included 4 isolates of $E$. coli and single isolate of E. aerogenes, P. mirabilis, C. youngae, and P. vulgaris (Table-2). The CTX-M enzyme was identified in five strains among of beta-lactamase-producing isolates, as a single isolate of E. coli, K. pneumonia, E. cloacae, K. oxytoca and C. freundii (Table-2). Both of CMY-2 and DHA, a plasmid-mediated AmpC beta-lactamases were detected in two different isolate of E. coli (Table-2).

\section{Distribution of bla genes}

The ß-lactamase-producing isolates were distributed into two categories, the first harbored only one type of $\beta$-lactamase encoding gene, the second harbored two types (Table-2). Twelve (12/17) of the total beta-lactamase-producing entrerobacteria were harboring only one beta-lactamase encoding gene, including five strains of $E$. coli and a single isolate of E. cloacae, K. oxytoca, C. youngae, P. vulgaris, C. freundii, $P$. mirabilis and E. aerogenes.

The $b l a_{\text {TEM }}$, a narrow-spectrum B-lactamase was detected alone in 7 isolates; E. coli (3 isolates) and a single isolate of $C$. youngae, $P$. vulgaris, $P$. mirabilis and $E$. aerogenes. The $b l a_{\text {CTX-M, }}$ an extended-spectrum ß-lactamase was detected alone in four isolates; single isolate of $K$. oxytoca from Yemen linnet feces, E. coli from common kestrel, E. cloacae from rock dove, and C. freundii from African gray parrot (Table-3). The plasmid-mediated ß-lactamases, bla ${ }_{\mathrm{CMY}-2}$ and $b l a_{\mathrm{DHA}}$ were detected in two different $E$. coli isolates recovered from Arabian red fox and Hill Mynah, respectively.

A total of two (2/17) of the total beta-lactamase-producing isolates were harboring gene combinations of $b l a_{\mathrm{TEM}}$ and $b l a_{\mathrm{DHA}}$ in E. coli recovered from the feces of Hill Mynah and bla $a_{\mathrm{TEM}}$ and bla $a_{\mathrm{CTX}-\mathrm{M}}$ in K. pneumonia delivered from the feces of baboon monkey.

\section{Discussion}

The resistance to beta-lactam and beta-lactamase inhibitors is of great clinical significance in several countries. Resistance to beta-lactam antibiotics is primarily mediated by beta-lactamases production. Many different $\beta$-lactamases have been described, but TEM, SHV, OXA, CMY-2, and CTX-M $\beta$-lactamases are currently regarded the most common among Enterobacteriaceae spp. [2].

Recently, many studies carried out in different countries describing the prevalence and characteristics of beta-lactamase gene harbored Enterobacteriaceae in wildlife free-living Canada geese in Georgia and North California [19], wild animals in Portugal [8,20], zoo animals in Japan [21], black-headed gulls in the 
Table-1: Primers used in this study to detect beta-lactamase (bla) genes.

\begin{tabular}{|c|c|c|c|c|c|}
\hline $\begin{array}{l}\text { Primer } \\
\text { target }\end{array}$ & $\begin{array}{l}\text { Primer } \\
\text { name }\end{array}$ & Sequence $\left(5^{\prime}-3^{\prime}\right)$ & $\begin{array}{l}\text { Annealing } \\
\text { temperature }\end{array}$ & $\begin{array}{l}\text { Product } \\
\text { size (bp) }\end{array}$ & Reference \\
\hline $\begin{array}{l}\text { TEM } \\
\left(b / a_{\text {TEM }}\right)\end{array}$ & $\begin{array}{l}\text { TEM-F } \\
\text { TEM-R }\end{array}$ & $\begin{array}{l}\text { AGTGCTGCCATAACCATGAGTG } \\
\text { CTGACTCCCC GTCGTGTAGATA }\end{array}$ & $61^{\circ} \mathrm{C}$ for $1 \mathrm{~min}$ & 431 & {$[18]$} \\
\hline $\begin{array}{l}\mathrm{SHV} \\
\left(b^{\prime} / a_{\mathrm{SHV}}\right)\end{array}$ & $\begin{array}{l}\text { SHV-F } \\
\text { SHV-R }\end{array}$ & $\begin{array}{l}\text { GATGAACGCTITCCCATGATG } \\
\text { CGCTGTTATCGCTCATGGTAA }\end{array}$ & $61^{\circ} \mathrm{C}$ for $1 \mathrm{~min}$ & 214 & {$[18]$} \\
\hline $\begin{array}{l}\text { CTX-M } \\
\left(\text { bla }_{\text {CTX-M }}\right)\end{array}$ & $\begin{array}{l}\text { CTX-M-F } \\
\text { CTX-M-R }\end{array}$ & $\begin{array}{l}\text { ATGTGCAGYACCAGTAARGTKATGGC } \\
\text { TGGGTRAARTARGTSACCAGAAYCAGCGG }\end{array}$ & $61^{\circ} \mathrm{C}$ for $1 \mathrm{~min}$ & 593 & [17] \\
\hline $\begin{array}{l}\text { OXA } \\
\left(\text { bla }_{\text {OXA }}\right)\end{array}$ & $\begin{array}{l}\text { OXA-F } \\
\text { OXA-R }\end{array}$ & $\begin{array}{l}\text { ACACAATACATATCAACTTCGC } \\
\text { AGTGTGTTTAGAATGGTGATC }\end{array}$ & $61^{\circ} \mathrm{C}$ for $1 \mathrm{~min}$ & 813 & [17] \\
\hline $\begin{array}{l}\text { PampC } \\
\left(\text { bla }_{\text {CMY }-2}\right)\end{array}$ & $\begin{array}{l}\text { CMY-F2 } \\
\text { CMY-R2 }\end{array}$ & $\begin{array}{l}\text { AGCGATCCGGTCACGAAATA } \\
\text { CCCGTITTATGCACCCATGA }\end{array}$ & $61^{\circ} \mathrm{C}$ for $1 \mathrm{~min}$ & 695 & [18] \\
\hline $\begin{array}{l}\text { PampC } \\
\left(\text { bla } a_{\mathrm{DHA}}\right)\end{array}$ & $\begin{array}{l}\text { DHA (F) } \\
\text { DHA (R) }\end{array}$ & $\begin{array}{l}\text { GTGGTGGACAGCACCATTAAA } \\
\text { CCTGCGGTATAGGTAGCCAGAT }\end{array}$ & $61^{\circ} \mathrm{C}$ for $1 \mathrm{~min}$ & 314 & {$[18]$} \\
\hline
\end{tabular}

Table-2: Prevalence and multiplicity of $\beta$-Lactamase genes among ESBLs- positive fecal bacteria derived from wild pet animals in Saudi Arabia.

\begin{tabular}{|c|c|c|c|c|c|c|c|}
\hline \multirow{2}{*}{$\begin{array}{l}\text { Bacterial } \\
\text { species }\end{array}$} & \multirow{2}{*}{$\begin{array}{c}\text { ESBL } \\
\text { positive no }\end{array}$} & \multicolumn{6}{|c|}{$\beta$-Lactamase- associated genes } \\
\hline & & TEM & CTX-M & CMY-2 & CTX-M, TEM & TEM, DHA & Total \\
\hline E. coli & 9 & 3 & 1 & 1 & - & 1 & 6 \\
\hline K. pneumonia & 1 & - & - & - & 1 & - & 1 \\
\hline P. mirabilis & 1 & 1 & - & - & - & - & 1 \\
\hline E. cloacae & 1 & - & 1 & - & - & - & 1 \\
\hline K. oxytoca & 1 & - & 1 & - & - & - & 1 \\
\hline C. youngae & 1 & 1 & - & - & - & - & 1 \\
\hline C. freundii & 1 & - & 1 & - & - & - & 1 \\
\hline P. vulgaris & 1 & 1 & - & - & - & - & 1 \\
\hline E. aerogenes & 1 & 1 & - & - & - & - & 1 \\
\hline Total & 17 & 7 & 4 & 1 & 1 & 1 & 14 \\
\hline
\end{tabular}

E. aerogenes=Enterobacter aerogenes, K. pneumonia=Klebsiella pneumonia, $K$. oxytoca=Klebsiella oxytoca, $P$. mirabilis=Proteus mirabilis, $P$. vulgaris=Proteus vulgaris, $E$. cloacae=Enterobacter cloacae, $C$. freundii=Citrobacter freundii, $C$. youngae=Citrobacter youngae, TEM=Temoneira, DHA=Dhahran, CTX-M=Cefotaxime - Munich, $\mathrm{CMY}=$ Cephamycinase, SHV=Sulfhydryl Variable, ESBL=Extended spectrum $\beta$-Lactamase

Table-3: Genotypic characteristics and occurrence of $\beta$-lactamases encoding genes in enterobacteria from wild pet animals.

\begin{tabular}{lllll}
\hline $\begin{array}{l}\text { Isolate } \\
\text { ID }\end{array}$ & Bacteria (no) & Animal species (scientific name) & bla gene & $\begin{array}{l}\text { Beta-lactam resistance } \\
\text { phenotype }\end{array}$ \\
\hline RH-1 & E. coli $(1)$ & Rock hyrax (Procavia capensis) & TEM & AMP, CEP \\
CK-3 & E. coli $(1)$ & Common kestrel (Falco tinnuculus) & CTX-M & AMP, CEP, AZT, CXM, CTX, CAZ \\
HM-7 & E. coli $(1)$ & Hill mynah (Gracula religosa) & TEM, DHA & $\begin{array}{l}\text { AMC, AMP, CEP, AZT, CXM, } \\
\text { CTX, CAZ, FOX }\end{array}$ \\
AF-17 & E. coli $(1)$ & Arabian red fox (Vulpes vulpes) & CMY-2 & AMC, AMP, CEP, AZT, CXM, \\
& & & & CTX, CAZ FEP, FOX \\
OP-22 & P. mirabilis (1) & Orange-winged Parrot (Amazona amazonica) & TEM & AMP, CEP \\
BP-19 & C. youngae (1) & Burmese python (Python molurus) & TEM & AMP, CEP \\
LF-27 & E. aerogene (1) & Long-tailed finches (Taeniopygia guttata) & TEM & AMP, CEP \\
RD-33 & E. cloacae (1) & Rock dove (Columba livia) & CTX-M & AMP, CEP, CXM, AZT, CAZ \\
PC-6 & P. vulgaris (1) & Peacock (Pavo cristatus) & TEM & AMP, CEP \\
BM-11 & K. pneumonia (1) & Baboon Monkey (Papio hamadryas) & TEM, CTX-M & AMP, CEP, CXM, AZT, CAZ \\
CA-31 & E. coli $(1)$ & Caracal (Caracal caracal) & TEM & AMP, CEP \\
CM-29 & E. coli $(1)$ & Common myna (Acridotheres tristis) & TEM & AMP, CEP \\
YL-8 & K. oxytoca (1) & Yemen linnet (Carduelis yemenensis) & CTX-M & AMP, CEP, AZT, CEF, CXM, CAZ \\
AP-13 & C. freundii (1) & African gray parrot (Psittacus erithacus) & CTX-M & AMP, CEP, AZT, CXM, CTX, CAZ \\
\hline
\end{tabular}

E. aerogenes=Enterobacter aerogenes, $K$. pneumonia=Klebsiella pneumonia, $K$. oxytoca=Klebsiella oxytoca, $P$. mirabilis $=$ Proteus mirabilis, $P$. vulgaris $=$ Proteus vulgaris, E. cloacae=Enterobacter cloacae, C. freundii=Citrobacter freundii, $C$. youngae=Citrobacter youngae

Czech Republic [4] and wild birds and free-range poultry in Bangladesh [22]. Since there seem to be geographical variations in the occurrence of different ESBLs, we describe prevalence and characteristics of ESBL/AmpC-genotypes within enterobacterial isolates from wild pet animals presenting at live animal market in Taif, Western Saudi Arabia.

\section{Prevalence of beta-lactamase genes}

The beta-lactamase genes harboring enterobacterial isolates from wild pet animals were detected in 
14 out of 17 isolates including six E. coli and single isolate of $K$. pneumonia, P. mirabilis, E. cloacae, $K$. oxytoca, C. youngae, C. freubdii, P. vulgaris, and $E$. aerogenes. The rate of bla genes in this study was consistent with that previously reported $[8,20,21]$, whereas E. coli is the most prevalent and encountered bla genes among enterobacteria from wild animals.

\section{Determination of the types of bla genes}

In this study, PCR screening revealed detection of beta-lactamase encoding genes of TEM, CTX-M, $\mathrm{CMY}$, and DHA. None of the isolates were positive for $b l a_{\mathrm{OXA}}$ and $b l a_{\mathrm{SHV}}$. The remaining three isolates did not show any of the bla genes investigated. Similarly, previous studies also detected many $\beta$-lactamase-encoding genes in wild animals [12,14,20,21,22].

A TEM- $\beta$-lactamase is a narrow-spectrum beta-lactamase gene, which confers resistance against penicillin's and first-generation cephalosporins [23]. In this study, bla $_{\text {TEM }}$ being detected in 7 isolates out of 17 enterobacteria-producing beta-lactamase as a sole mechanism of resistance to beta-lactams and all these isolates showed an ampicillin, cephalothin and or cefuroxime resistance phenotypes. TEM- $\beta$-lactamase has been previously detected in fecal isolates from magpies and wild rabbits from West Wales [24], free-living Canada geese in Georgia and North Carolina [19], wild animals in Portugal [20], Zoo animals in Japan [21], black-headed gulls in the Czech Republic [4], yellow-legged gulls in France [5], imported flamingos in Japan [25], gulls population in Sweden [12], migratory and resident population of rooks in Austria [26], seagulls and crows in Bangladesh [27].

Recently, there has been worldwide increase in the incidence of ESBLs [3]. In this study, bla ${ }_{\text {СтХ-м }}$, an ESBL-encoding gene, was detected in five isolates of enterobacteria from feces of wild animals. The $b l a_{\text {CTX-M }}$ has been previously identified in fecal bacteria from wild animals in Portugal [20], masked palm civet in Japan [21], imported flamingos in Japan [25], gulls in Sweden [12], migrating and resident population of rooks in Austria [26].

Furthermore, the plasmid-mediated AmpC genes (bla ${ }_{\mathrm{CMY}-2}$ and $\left.b l a_{\mathrm{DHA}}\right)$, were observed in two of strains of enterobacteria showed a typical AmpCbeta-lactamase resistance phenotype. The presence of AmpC $\beta$-lactamases have been found worldwide but are less common than ESBLs [28]. The information on the presence of AmpC producing Enterobacteriaceae in wildlife is scarce. Recently, the bla ${ }_{\mathrm{CMY}}$ has been reported previously from jaybird isolates of $K$. oxytoca in Japan [21], migrating and resident population of rooks in Austria [26]. The bla ${ }_{\mathrm{DHA}}$ was the first identified from clinical isolates of Salmonella enteritidis in Saudi Arabia [29]. Recently, in Magnolia, the $b l a_{\text {DHA }}$ was detected in one E. coli from clinical sources [30].

\section{Analysis of bla genes multiplicity among isolates}

As in previous studies, bla-genes in this study were detected within enterobacteria from wild animals either as a single gene loci or as gene combination of two or more gene loci for beta-lactamases $[13,21,26]$.

A comparative view of Arabian Gulf region and Saudi Arabia showed a high occurrence of ESBLproducing isolates harboring TEM, SHV, OXA, and CTX-M- $\beta$-lactamases from hospitals [16,31-34] and raw chicken [35].

\section{Conclusions}

It is of interest the detection of ESBL/AmpCproducing bacteria in wild animals at pet market. This is the first study, to our knowledge, of enterobacteria harboring $\beta$-lactamase genes in wild animals in Saudi Arabia. The fact that these animals often live in close contact with their owners and other people in market make the occurrence of transmission between them even more likely. More studies should be carried out in the future in order to track the variants and evolution of $\beta$-lactamase genes compared to those from human isolates.

\section{Authors' Contributions}

SAH conceived, designed the study, drafted and revised the manuscript. MYS collected and analyzed samples. Both authors read and approved the final manuscript.

\section{Acknowledgements}

The authors are grateful for financial support of deanship of scientific research of Taif University, Saudi Arabia (project no. 1/435/3319).

\section{Competing Interests}

The authors declare that they have no competing interests.

\section{References}

1. Bush, K., Jacoby, G.A. and Medeiros, A.A. (1995) A functional classification scheme for $\beta$-lactamases and its correlation with molecular structure. Antimicrob. Agents Chemother., 39(6): 1211-1233.

2. Bradford, P.A. (2001) Extended spectrum $\beta$-lactamases in the $21^{\text {st }}$ century: Characterization, epidemiology and the detection of this important resistance threat. Clin. Microbiol. Rev., 14: 933-951.

3. Paterson, D.L. and Bonomo, R.A. (2005) Extended spectrum beta-lactamases: A clinical update. Clin. Microbiol. Rev., 18: 657-686.

4. Dolejska, M., Cizek, A. and Literak, I. (2007) High prevalence of antimicrobial-resistant genes and integrons in Escherichia coli isolates from black-headed gulls in the Czech Republic. J. Appl. Microbiol., 103: 11-19.

5. Bonnedahl, J., Drobni, M., Gauthier-Clerc, M., Hernandez, J., Granholm, S., Kayser, Y., Melhus, A., Kahlmeter, G., Waldenstrom, J., Johansson, A. and Olsen, B. (2009) Dissemination of Escherichia coli with CTX-M type ESBL between humans and yellow-legged gulls in the South of France. PLoS One, 4: e5958.

6. Literak, I., Dolejska, M., Janoszowska, D., Hrusakova, J., Meissner, W., Rzyska, H., Bzoma, S. and Cizek, A. (2010) Antibiotic resistant Escherichia coli bacteria, including strains with genes encoding the extended-spectrum beta-lactamase and QnrS, in water birds on the Baltic Sea Coast of Poland. Appl. Environ. Microbiol., 76: 8126-8134. 7. Guenther, S., Grobbel, M., Beutlich, J., Bethe, A., 
Friedrich, N.D., Goedecke, A., Luebke-Becker, A., Guerra, B., Wieler, L.H. and Ewers, C. (2010) CTX-M15 type extended-spectrum beta-lactamases-producing Escherichia coli from wild birds in Germany. Environ. Microbiol. Rep., 2: 641-645.

8. Pinto, L., Radhouani, H., Coelho, C., Martins da Costa, P., Simoes, R., Brandao, R.M., Torres, C., Igrejas, G. and Poeta, P. (2010) Genetic detection of extended spectrum beta-lactamase-containing Escherichia coli isolates from birds of prey from Serra da Estrela Natural Reserve in Portugal. Appl. Environ. Microbiol., 76: 4118-4120.

9. Radhouani, H., Pinto, L., Coelho, C., Goncalves, A., Sargo, R., Torres, C., Igrejas, G. and Poeta, P. (2010) Detection of Escherichia coli harboring extended-spectrum beta-lactamases of the CTX-M classes in faecal samples of common buzzards (Buteo buteo). J. Antimicrob. Chemother., 65: 171-173.

10. Garmyn, A., Haesebrouck, F., Hellebuyck, T., Smet, A., Pasmans, F., Butaye, P. and Martel, A. (2011) Presence of extended spectrum beta-lactamase-producing Escherichia coli in wild geese. J. Antimicrob. Chemother., 66: 1643-1644.

11. Silva, N., Igrejas, G., Rodrigues, P., Rodrigues, T., Goncalves, A., Felgar, A.C., Pacheco, R., Goncalves, D., Cunha, R. and Poeta, P. (2011) Molecular characterization of vancomycin-resistant Enterococci and extended-spectrum beta-lactamase-containing Escherichia coli isolates in wild birds from the Azores Archipelago. Avian Pathol., 40: 473-479.

12. Wallensten, A., Hernandez, J., Ardiles, K., GonzálezAcuña, D., Drobni, M. and Olsen, B. (2011) Extended spectrum beta-lactamases detected in Escherichia coli from gulls in Stockholm, Sweden. Infect. Ecol. Epidemiol., 1: 7030

13. Goncalves, A., Igrejas, G., Radhouani, H., Estepa, V., Alcaide, E., Zorrilla, I., Serra, R., Torres, C. and Poeta, P. (2012) Detection of extended-spectrum beta-lactamase-producing Escherichia coli isolates in faecal samples of Iberian lynx. Lett. Appl. Microbiol., 54: 73-77.

14. Radhouani, H., Igrejas, G., Goncalves, A., Estepa, V., Sargo, R., Torres, C. and Poeta, P. (2013) Molecular characterization of extended-spectrum beta lactamase-producing Escherichia coli isolated from red foxes in Portugal. Arch. Microbiol., 195(2): 141-144.

15. Mokaddas, E.M., Abdulla, A.A., Shati, S. and Rotimi, V.O. (2008) The technical aspects and clinical significance of detecting extended-spectrum beta-lactamase producing Enterobacteriaceae at a tertiary-care hospital in Kuwait. $J$. Chemother., 20: 445-451.

16. Al-Agamy, M.H., Shibl, A.M. and Tawfic, A.F. (2009) Prevalence and molecular characterization of extended-spectrum beta-lactamase producing Klebsiella pneumoniae in Riyadh, Saudi Arabia. Ann. Saudi Med., 29: 253-257.

17. Fang, H., Ataker, F., Hedin, G. and Dornbusch, K. (2008) Molecular epidemiology of extended-spectrum beta-lactamases among Escherichia coli isolates collected in a Swedish hospital and its associated health care facilities from 2001 to 2006. J. Clin. Microbiol., 46(2): 707-712.

18. Kim, J., Jeon, S., Rhie, H., Lee, B., Park, M., Lee, H., Lee, J. and Kim, S. (2009) Rapid detection of extended spectrum $\beta$-Lactamase (ESBL) for Enterobacteriaceae by use of a multiplex PCR-based method. Infect. Chemother., 41(3): 181-184.

19. Cole, D., Drum, D.J., Stalknecht, D.E., White, D.G., Lee, M.D., Ayers, S., Sobsey, M. and Maurer, J.J. (2005) Freeliving Canada geese and antimicrobial resistance. Emerg. Infect. Dis., 11: 935-938.

20. Costa, D., Poeta, P., Saenz, Y., Vinue, L., Rojo-Bezares, B., Jouini, A., Zarazaga, M., Rodrigues, J. and Torres, C. (2006) Detection of Escherichia coli harbouring extended-spectrum beta-lactamases of the CTX-M, TEM and SHV classes in faecal samples of wild animals in Portugal. J. Antimicrob. Chemother., 58: 1311-1312.

21. Ahmed, A.M., Motoi, Y., Sato, M., Maruyama, A., Watanabe, H., Fukumoto, Y. and Shimamoto, T, (2007) Zoo animals as reservoirs of gram-negative bacteria harboring integrons and antimicrobial resistance genes. Appl. Environ. Microbiol., 73: 6686-6690.

22. Hasan, B., Sandegren, L., Melhus, A., Drobni, M., Hernandez, J., Waldenstroem, j., Alam, M. and Olsen, B. (2012) Antimicrobial drug-resistant Escherichia coli in wild birds and free-range poultry, Bangladesh. Emerg. Infect. Dis., 18(12): 2055-2058.

23. Livermore, D.M. and Woodford, N. (2006) The $\beta$-lactamase threat in Enterobacteriaceae, Pseudomonas and Acinetobacter. Trends Microbiol., 14: 413-420.

24. Livermore, D.M., Warner, M., Hall, L.M., Enne, V.I., Projan, S.J., Dunman, P.M., Wooster, S.L. and Harrison, G. (2001) Antibiotic resistance in bacteria from magpies (Pica pica) and rabbits (Oryctolagus cuniculus) from West Wales. Environ. Microbiol., 3: 658-661.

25. Sato, M., Ahmed, A.M., Noda, A., Watanabe, H., Fukumoto, Y. and Shimamoto, T. (2009) Isolation and molecular characterization of multidrug-resistant Gramnegative bacteria from imported flamingos in Japan. Acta Vet. Scand., 51: 46-50.

26. Loncaric, I., Stalder, G.L., Mehinagic, K., Rosengarten, R., Hoelzl, F., Knauer, F. and Walzer, C. (2013) Comparison of ESBL - and AmpC producing Enterobacteriaceae and methicillin-resistant Staphylococcus aureus (MRSA) isolated from migratory and resident population of rooks (Corvus frugilegus) in Austria. PLoS ONE, 8(12): e84048.

27. Hasan, B. (2013) Antimicrobial resistance and production of extended spectrum beta-lactamases in Enterobacteriaceae from birds in Bangladesh. Acta Universitatis Upsaliensis, Uppsala. p911-975.

28. Jacoby, G.A. (2009) AmpC beta-lactamases. Clin. Microbiol. Rev., 22: 161-182.

29. Barnaud, G., Arlet, G., Verdet, C., Gaillot, O., Lagrange, P.H. and Philippon, A. (1998) Salmonella enteritidis: AmpC plasmid-mediated inducible-lactamase (DHA-1) with an ampR gene from Morganella morganii. Antimicrob. Agents Chemother., 42: 2352-2358.

30. Kaftandzieva, A., Trajkovska-Dokic, E. and Panovski, N. (2011) Prevalence and molecular characterization of extended spectrum beta-lactamases (ESBLs) producing Escherichia coli and Klebsiella pneumonia. Sec. Biol. Med. Sci., XXXII(2): 129-141.

31. Rotimi, V.O., Jamal, W., Pal, T., Sovenned, A. and Albert, M.J. (2008) Emergence of CTX-M-15 type extended-spectrum beta-lactamase-producing Salmonella spp. in Kuwait and the United Arab Emirates. J. Med. Microbiol., 57: 881-886.

32. Bindayna, K.M., Khanfar, H.S., Senok, A.C. and Botta, G.A. (2010) Production of CTX-M genotype among ESBLisolates in a tertiary hospital in Saudi Arabia. Saudi Med. J., 31: 859-863.

33. Alsultan, A.A., Abulmagd, E. and Amin, T.T. (2013) Extended beta-lactamse-producing Escherichia coli and Klebsiella pneumoniae in Al-Ahsa, Saudi Arabia: Antibiotic susceptibility and production of $b l a_{\mathrm{SHV}}$ and $b l a_{\mathrm{TEM}}$. J. Infect. Dev. Ctries., 7: 1016-1019.

34. Mohmid, E.A., El-Sayed, E.A. and Abdel El-Haliem, M.F. (2013) Molecular study on extended spectrum beta-lactam producing Gram-negative bacteria isolated from Ahmadi hospital in Kuwait. Afr. J. Biotechnol., 12: 5040-5035.

35. Altalhi, A.D., Gherbawy, Y.A. and Hassan, S.A (2010) Antibiotic resistance in Escherichia coli isolated from retail raw chicken meat in Taif, Saudi Arabia. Foodborne Pathog. Dis., 7: 281-285. 